\title{
Traditional fisherfolk and no-take protected areas: The Peixe Lagoon National Park dilemma
}

\author{
Tiago Almudi*, Daniela Coswig Kalikoski \\ Federal University of Rio Grande, Institute of Human Sciences and Information, Av. Itália km 8, Caixa Postal 474, Rio Grande, RS, Brazil
}

\section{A R T I C L E I N F O}

\section{Article history:}

Available online 13 April 2010

\begin{abstract}
A B S T R A C T
This study challenges the 'National Park' as the appropriate management model for the Peixe Lagoon area in southern Brazil through an investigation of local fisherfolk livelihoods and traditional ecological knowledge. We argue that top-down management policies implemented through a non-participatory process, which have resulted in conflict between government officials and fisherfolk, disregarded the fisherfolk's cultural practices and particular knowledge, thereby violating their rights as traditional people. Multiple suggestions are provided to achieve environmental conservation schemes without compromising the local traditional fishing livelihoods.
\end{abstract}

(c) 2010 Elsevier Ltd. All rights reserved.

\section{Introduction}

This study focuses on the conflicts between state agents and traditional fishers for the preservation or use of natural resources in the Peixe Lagoon National Park, southern Brazil. National Parks as units of conservation (term used to refer to protected areas in Brazil) legally prohibit the exploitation of fish, timber and other natural resources [9]. The creation of the Park, thereby made illegal the presence of the traditional fisherfolk who have inhabited this area for centuries. In the year 2000 the Brazilian National System of Conservation Units (locally known as SNUC), completely reworked the existing national system for creating protected areas. Under Law $n^{\circ} 9985 / 00$ SNUC brought together all categories of conservation units in Brazil and established the guidelines for their creation and management. Those categories are divided in two main groups: integral protection conservation units and sustainable use conservation units. The basic difference between them is that extraction of natural resources is allowed in the first group and forbidden in the second (Table 1 ).

SNUC mandates that traditional people have their culture and ways of life protected and valued, and that implementation and management of conservation units is done democratically and in partnership with local people. Created in 1986, prior to current SNUC, the Peixe Lagoon National Park was established without involving the population that historically inhabited the region. At

\footnotetext{
* Corresponding author. Tel.: +55 4135217793.

E-mail addresses: tiagoalmudi@yahoo.com.br (T. Almudi), danielak@furg.br (D.C. Kalikoski).
}

that time, there were no such sustainable use conservation units, and categories such as National Park and Ecological Station were the most commonly implemented units of conservation. Although Peixe Lagoon National Park was created when this policy for public participation was not in place, today its administration has not adapted to include local fishers, who we argue are 'traditional people', into protected area management. Public involvement in this case has been poor as fishers are not pleased with their lack of long-term rights to access resources. Beyond poor public participation, lack of rights threatening livelihoods has aroused serious conflicts including civil disobedience and physical violence.

The participatory approach mandated by SNUC was developed as a political response to a worldwide shift in approaches to environmental management that attempts to recognize the importance of indigenous and traditional knowledge and to grant rights to these people. The definition of traditional people is often controversial. Usually the term 'traditional' entails residence in a certain area for a long period [10]. Several authors have attempted to define traditional people, and some of the common features of such definitions include: direct dependence on natural resources for livelihoods and source of income, non-industrial and low technological orientation [7], and rich empirical knowledge about local ecological processes [21]. Examples of such peoples in Brazil are artisanal fishers and extractives groups, among others characterized by close ties to the nature $[4,15]$.

The ecological knowledge held by traditional peoples (the socalled traditional ecological knowledge - TEK) is defined as "the cumulative body of knowledge, practices and values, developed by adaptive processes and transferred through generations by cultural ways, being concerned to the relations among the living beings 
Table 1

Types of Brazilian protected areas and their main purposes (Brazil 2000).

\begin{tabular}{lll}
\hline $\begin{array}{l}\text { Types of } \\
\text { Protected Area }\end{array}$ & Main Purpose & Examples \\
\hline $\begin{array}{l}\text { Group I } \\
\text { integral protection }\end{array}$ & $\begin{array}{l}\text { Environmental preservation } \\
\text { without direct use of }\end{array}$ & $*$ National Park \\
& natural resources & $*$ Biological Reserve \\
& Ecological Station \\
Group II & Environmental conservation & - Extrlife Reserve \\
sustainable use & combined with sustainable & - Reserve of Sustainable \\
& use & Development \\
& & - Area of Environmental \\
& & Protection \\
\hline
\end{tabular}

(including humans) and between living beings and the environment" [7, p. 8]. According to Berkes [7], such knowledge provides a close bound between local peoples and their environment. Many authors have demonstrated that fisherfolk's traditional ecological knowledge is a key aspect to be considered for fisheries management purposes [15,20,25].

This paper is based on a theoretical body of literature that considers the importance of dealing with environmental preservation in the context of an adaptive and integrated social-ecological system $[6,7,14,16,21,33]$. In this 'co-evolutive' system, economy, the natural environment and society are visualized together as interacting and overlapping features of the same complex system [21]. In this context we looked at new ways of approaching and dealing with environmental problems where dialogue among stakeholders is continuously stimulated and motivated to achieve sustainable development $[28,39]$.

Contrary to the North-American model of National Parks, that rely on theory from deep ecology and were largely imposed to tropical countries in the south hemisphere [15], the conservation approach developed in India during the eighties affirms that traditional societies require high diversity of natural resources and that these societies continue to exist because they have developed cultural practices of resource use that maintain their cultural values and local biodiversity [41]. Consequently, the maintenance and survival of such practices in same cases could be an excellent strategy to conserve biological diversity [34]. In contrast, deep ecology is a thought line which defends that the human activities necessarily imply in environmental degradation [15]. Then, sublime and 'untouched' landscapes became an urgent object of protection [41].

Diegues [14] affirms that this model was generated in the last century in a historical and social context of the United States when there was a disordered occupation of the territory together with intense urbanization. Human beings were considered naturally destroyers of the environment independently of the social formation they were inserted in. On the other hand, Godelier [18] shows innumerable studies that have demonstrated that the destructive character of the relationship between humans and nature largely depends on the characteristics and rationality inherent to a diverse social-cultural environment. In fact, in many parts of the world there have been examples of resource user communities that have been engaged as partners in the protection of areas of high ecological significance $[11,29,35]$.

Following a description of the site history and context, we examine the legitimacy of the current National Park as the most appropriate category of conservation unit in the case of Peixe Lagoon. We then assess the role of fisherfolks' traditional knowledge and fishing practices as key elements for environmental conservation in the Peixe Lagoon. Finally, we discuss the advantages and barriers of integrating the traditional people in resource management and protected area conservation.

\section{Case-study: Peixe Lagoon National Park, Southern Brazil}

The Peixe Lagoon is situated on the coast of Rio Grande do Sul, the southernmost Brazilian state, in the narrow sandy strip between the Patos Lagoon and the Atlantic Ocean. Due to difficulties of access to this region, it has had minimal urban development. Only two small cities (Tavares and Mostardas), which together have approximately eighteen thousand inhabitants, are located in the surroundings of the Peixe Lagoon [47].

Since the first Azorean Portuguese immigrants occupied the region in the middle of the eighteen century the region occupants have practiced agriculture, raised cattle and fished in the lagoon and adjacent ocean [46]. Although both small scale farmers and fisherfolk currently occupy the region, this study focused on the fisherfolks based on the hypothesis that they can be characterized as traditional peoples according to the criteria established by Diegues [15], as presented in Table 2 .

The fisherfolk villages are located in beach zones, a few kilometres away from the urban areas. Of the five existing villages, three are located inside the National Park (around fifty families in total) and two are located outside the Park (around forty families in total). Only the villages located inside the Park are on the edges of the Peixe Lagoon.

The Lagoon periodically connects to the sea and serves as a nursery and feeding place for diverse species of mollusks, crustaceans and fish, among other typical estuarine species [27]. For this reason the Peixe Lagoon also presents a great abundance of endemic and migratory birds that periodically visit the area while migrating from the south (Argentina) and from the northern hemisphere (Canada) [37]. Due to the abundance and richness of birds, this region attracted the interest of local and international researchers during the 80's [37]. Based on the recognition of the importance of this Lagoon for the migratory birds, the former Brazilian Institute for Forest Development (IBDF), current Brazilian Institute for the Environment and Renewable Natural Resources (IBAMA), decided to transform the area into a National Park. Its area corresponds to 34,000 ha, including not only the Peixe Lagoon but also surrounding ecosystems such as spit forests, dunes, beaches and small fresh water lakes. In 2007, Instituto Chico Mendes de Conservação da Biodiversidade (ICMBio) took over the mandate of IBAMA to create and manage protected areas in Brazil. When this research was being implemented, Peixe Lagoon IBAMA staff was still being transferred to ICMBio. For this reason we still refer to the Park administration as IBAMA in this paper.

According to the SNUC and Decree $n^{\circ} 4340 / 02$, people who inhabit a National Park must be removed and relocated, and the exploitation of natural resources is forbidden. The category of National Parks given by SNUC is a restrictive type of conservation unit and does not allow any type of extractive activities nor does it allow people to live inside the park borders. This has generated a serious conflict between the federal environmental agency (IBAMA) and local people because government's responsibilities are to enforce legislation and remove the locals despite their historical dependence on fisheries for survival and use of rudimentary tools for fishing [2].

According to Park officials, IBAMA has not yet removed the fisherfolks from the Peixe Lagoon National Park as required by SNUC law due to lack of structure, staff, and financial resources. In order to minimize conflicts while relocation is not possible, an agreement was made within the Peixe Lagoon Fisheries Forum, in which a hundred and sixty-six (166) fishers were granted by IBAMA a temporary license to work and live inside the National Park. The criteria used to grant such licenses were based and adapted from the notion of traditional people as provided by Diegues. Fishers who were able to fulfill the following criteria 
Table 2

Peixe Lagoon fishers characterized as traditional peoples.

\begin{tabular}{|c|c|}
\hline Traditional people (Diegues 1996, p. 87) & Peixe Lagoon fishers characteristics \\
\hline $\begin{array}{l}\text { a) Great dependence of renewable natural resources, } \\
\text { from that they construct a particular way of life. }\end{array}$ & $\begin{array}{l}\text { Direct dependency of fisheries for subsistence, food } \\
\text { security and as source of income. }\end{array}$ \\
\hline $\begin{array}{l}\text { b) Detailed knowledge about the local environment used for resource management } \\
\text { and conservation. This knowledge is transferred orally from generation to generation. }\end{array}$ & $\begin{array}{l}\text { High level of knowledge about the species caught } \\
\text { and ecosystems in which they occur. } \\
\text { Transference of knowledge from elders to the youth during } \\
\text { day-to-day fishing activities. }\end{array}$ \\
\hline $\begin{array}{l}\text { c) Sense of belonging to a territory where the group } \\
\text { reproduces its economy, society and symbols. }\end{array}$ & $\begin{array}{l}\text { Informal territorial rights and fishing accords defined by } \\
\text { fisherfolk and respected through generations. }\end{array}$ \\
\hline d) Permanence and occupation of a territory through several generations. & $\begin{array}{l}\text { Colonization of the region started in the } 18 \text { th century, when the first } \\
\text { immigrants arrived from Azores and maintained and adapted } \\
\text { their fishing practices until the present. }\end{array}$ \\
\hline e) Importance of subsistence activities. & $\begin{array}{l}\text { A considerable amount of the fisheries is used for } \\
\text { consume at fisherfolk's home. }\end{array}$ \\
\hline f) Reduced accumulation of capital. & Simple way of life with reduced accumulation of capital. \\
\hline $\begin{array}{l}\text { g) Great importance given to the familiar, domestic or communal unit of production, } \\
\text { and to the kinships for the exercise of economic, social and cultural activities. }\end{array}$ & $\begin{array}{l}\text { Some families are completely dependent and work on fishing } \\
\text { activities. The majority of wives and children of fishermen } \\
\text { assist in the harvest and post harvest activities. }\end{array}$ \\
\hline $\begin{array}{l}\text { h) Great importance attributed to the symbols, myths } \\
\text { and rituals associated to hunt and fisheries. }\end{array}$ & $\begin{array}{l}\text { Religion, local myths, folklore, local terminology } \\
\text { used is associated to fishing activities. }\end{array}$ \\
\hline i) Use of simple and family-based technologies, with low environmental impact. & Manual fishing practices and simple technologies. \\
\hline j) Weak politic influence and power. & $\begin{array}{l}\text { Politically marginalized (low level of formal } \\
\text { education and reduced accumulation of wealth). }\end{array}$ \\
\hline k) Cultural identity of the group. & $\begin{array}{l}\text { Fishing cultural identity that goes back to the Azorean } \\
\text { culture adapted to the present situation. }\end{array}$ \\
\hline
\end{tabular}

were granted the license, which is possible to be annually renewed: (I) to have the national fisher license provided by the federal government for more than 5 years, (II) to depend on fisheries inside the National Park for at least 10 years, (III) to live within the protected area or its buffer zone for at least 10 years, (IV) to use resources continually all over the year instead of opportunistic resource use, (V) to have at least $70 \%$ of income deriving from fisheries, and (VI) to be registered by the National Park staff in November every year [2].

Despite of such agreement allowing fishers to live and fish within the Park borders, fishers have complained that IBAMA officials and agents have historically applied informal pressure to cause people to leave their residences within the Park without providing due compensations and assistance for relocation. As a consequence, the villages inside the Park have declined and the fisherfolk have moved to nearby cities and to the villages outside the protected area.

The lack of participatory mechanisms for the implementation of the Peixe Lagoon National Park has led local people to be against the existence of this conservation unit. Locals question the legitimacy of the Park on the basis that it was imposed without appropriate popular consultation, disrespecting the local culture and traditional ways of living.

\section{Methodology}

Methods of investigation involved primary and secondary data. Primary data were collected using semi-structured in-depth interviews [12,13] with local fisherfolk and government officials. A total of forty (40) interviews were conducted with fishermen and a total of eleven (11) with government officials. These data were complemented by document analysis, including the Management Plan of the Peixe Lagoon National Park and local newspapers.

Local fisherfolk that live and fish in the region for a long time and that have a cumulative knowledge about local fisheries were selected to be interviewed following the snowball technique $[12,13]$. The duration of each interview varied from one to one and a half hours. All interviews were recorded in a digital voice recorder with the consent of the interviewees. Interviews focused on (1) the identification and description of fishing communities livelihoods; (2) traditional ecological knowledge and environmental management strategies used by local fishers and their match to the local environment; (3) understanding how the local fisherfolk were involved in the National Park establishment, and how they have been included in its current management. With that we intended to check whether Peixe Lagoon fishers qualify as traditional people, and therefore must have their culture, livelihoods and knowledge protected according to legislation, and to demonstrate whether their traditional knowledge could be useful for environmental and resource management, and more broadly used into protected area management.

The assessment of the role of traditional fisherfolk as possible partners for conservation and the relevance of their traditional ecological knowledge followed criteria proposed respectively by Diegues [16, p. 87] and Berkes [7, p. 29-35]. Diegues [16] characterizes traditional people according to the Brazilian context (Table 2), and Berkes [7] points out the attributes of TEK that are important for environmental management (Table 3). Such characteristics were tested by Kalikoski and Vasconcellos [25] in the Patos Lagoon estuary and by Seixas [44,45] in Ibiraquera Lagoon, both in Southern Brazil. The analysis centered on the hypothesis that fisherfolks' traditional ecological knowledge and institutions are key elements for successful environmental conservation in the Peixe Lagoon area. Results were validated through participant observation during the whole fieldwork period. The researcher followed fishers' daily activities, including social events, community gatherings and meetings of multi-stakeholder bodies such as the National Park Advisory Council.

\section{Peixe Lagoon fisherfolk livelihoods}

Fisheries take place not only in the Peixe Lagoon but also in the adjacent coastal waters. In the sea, fishers use three-mesh gillnets locally called 'feiticeira' to capture mainly southern kingfish (Menticirrhus littoralis, Menticirrhus americanus), mullet (Mugil spp), silverside (Austroatherina incisa, Odontesthes argentinensis, Xenimelaniris brasiliensis) and weakfish (Macrodon ancylodon). Bagnets are used to capture Argentine stiletto shrimp (Artemesia 
Table 3

Traditional ecological knowledge of Peixe Lagoon fishers.

\begin{tabular}{|c|c|}
\hline Populations that hold TEK (Berkes 1999, p. 29-35) & Peixe Lagoon fishers \\
\hline $\begin{array}{l}\text { a) Possess knowledge about the biota, life cycle of animals, ecosystems } \\
\text { cycles, and others that can be combined with scientific knowledge. }\end{array}$ & $\begin{array}{l}\text { Possess knowledge about local natural processes and the characteristics } \\
\text { of the species, mainly those related to fisheries. }\end{array}$ \\
\hline $\begin{array}{l}\text { b) Have potential to adaptive management, that is, they have } \\
\text { knowledge about how to adapt to specific situations. }\end{array}$ & $\begin{array}{l}\text { Traditionally open the Lagoon's mouth and have been involved in the } \\
\text { design of the regulations for the pink-shrimp fishery season. }\end{array}$ \\
\hline $\begin{array}{l}\text { c) Can assist in the conservation of protected areas, through } \\
\text { practices of sustainable exploitation. }\end{array}$ & $\begin{array}{l}\text { Control fishing territories as a practice resulting in protection against } \\
\text { resources over-exploitation. }\end{array}$ \\
\hline $\begin{array}{l}\text { d) Can help in environmental assessment because they have } \\
\text { knowledge about local peculiarities. }\end{array}$ & $\begin{array}{l}\text { Know about historical changes in the Lagoon's characteristics } \\
\text { related or not to human interventions (e.g. water depth). }\end{array}$ \\
\hline e) Help in the biodiversity conservation. & $\begin{array}{l}\text { Manage the Lagoon's mouth since the first part of the 19th } \\
\text { century by opening a ditch that connects the lagoon to the sea, } \\
\text { allowing the exchange of water, chemical compounds and organisms. } \\
\text { It creates biodiversity enrichment. }\end{array}$ \\
\hline $\begin{array}{l}\text { f) Can better assess local people's necessities, environmental risks that } \\
\text { may threaten them, and propose more adequate solutions. }\end{array}$ & $\begin{array}{l}\text { Capable to assess their own necessities and difficulties as a result from } \\
\text { the interaction with their local environment. }\end{array}$ \\
\hline $\begin{array}{l}\text { g) Express in its culture respect to nature and to moderate } \\
\text { resource exploitation. }\end{array}$ & $\begin{array}{l}\text { Demonstrate respectful use of resources, protecting fishery territories } \\
\text { and closing fisheries when shrimp size is small. }\end{array}$ \\
\hline
\end{tabular}

longinaris). Fishing is carried out without the use of boats but the fishers use old trucks to pull the nets to the land. This same action was formerly done by human traction. Fishing resources captured in the sea are widely used for subsistence, constituting important element for their food security. Fishers collect clams (Mesodema mactroides) mostly for subsistence, using their own hands or shovels.

In fisheries carried out at the Peixe Lagoon, fishers use small open boats made of wood, locally called 'caíco' [8]. These boats are approximately twenty feet long and are not motorized. The main targeted species is the pink-shrimp (Farfantepenaeus paulensis, Farfantepenaeus brasiliensis) which is caught with stownets. Gas lamps are used in order to attract the shrimps to the nets. Mullet, blueside and flatfish (Paralichthys orbignyana) are also fished in the lagoon. To capture those species the fisherfolk use one-mesh gillnets with less height than those used in the sea.

Fishing can be divided in two distinct seasons: summer, when there is a greater likelihood for commercialization, and winter, when the harvest is usually enough only for subsistence. In the summer time (from January to May), the efforts are concentrated in the pink-shrimp fisheries, which is the species with higher commercial value and therefore a major source of income. At the end of the summer, mullets are captured in the sea, especially in years when the pink-shrimp is scarce.

The primary species captured during the winter is the Argentine stiletto shrimp, which is caught during northeast wind conditions which generally starts in the end of July and goes until September. While the shrimp season does not start, southern kingfish is fished in the sea and mullet and blueside are fished in the lagoon. At the end of the winter season (from September to November), weakfish are targeted for capture. Although some fishers do make some profit during the winter, mostly it is insignificant, which explains the fact that most fishers stay at home fixing fishing nets and boats.

The majority of the families depend exclusively on fisheries for income, and the art of fishing is taught and learned in the family sphere. Children and women use to directly or indirectly participate in fishing activities. While many women do fish, others only participate in post-harvesting activities, such as cleaning fish and shrimp, catching clams, and washing boats.

Differently from the industrial fisheries in Brazil, artisanal fishers share part of their harvest with other people in the community such as widows, children, fishers' friends, neighbors and relatives. This production system diverges from the social and economic dynamics of mainstream society, in which profits maximization is the main aim [16].

The accumulation of wealth by Peixe Lagoon fishers is minimal. Their modest housing, which inside the National Park area lacks electricity and running water, is an example of their simple life style. Few fishers have means of transportation. The transport of the production is made mostly through the use of wagons with horse traction or old pick-up trucks.

Little use of other resources, such as small-scale cattle raising and household level agriculture, is made by some of the Peixe Lagoon fishers. First of all, roughly half of those fishers live in the small towns located in the surroundings of the Peixe Lagoon and have no access to lands to carry out productive activities. Second, fisheries products (especially the pink-shrimp) have been more profitable than livestock and agriculture. And last, raising cattle and planting are activities that have not been acceptable according to the policies adopted by National Park administration. Hunting and extraction of timber and non-timber products are very unusual activities among fishers, although there are large-scale Pinus plantations for commercial use which have been disputed in law by corporations.

Table 2 summarizes the characteristics of Peixe Lagoon fishers in comparison with the criteria established by Diegues to characterize traditional people in Brazil.

\section{The role of traditional ecological knowledge for conservation}

The knowledge involved in fisherfolk day-to-day activities is closely related to the Peixe Lagoon and adjacent coastal ecosystems as a consequence of their direct dependence on those environments for survival. Fisher's routine and fishing practices are shaped by and largely adapted to local environmental conditions such as wind and rain regimes.

We identified that Peixe Lagoon fisher's knowledge is especially rich in what relates to the weather, local ecosystems, species life cycles and their mutual interactions. Fishers know species behavior such as when they migrate to the Peixe Lagoon region, where they come from and the main purpose of migration. For example, mullet schools migrate to the Peixe Lagoon region in May, coming from the Patos Lagoon estuary seeking warmer waters, and later returns in sparse groups.

Fishers recognize that silverside and southern kingfish are species that stay closer to the coast, while the others swim in deeper waters. They also observe that some species, such as the pink-shrimp, depend on the Lagoon during their larvae cycle (locally called 'breeding') to grow, while others only eventually visit the Lagoon, never depending on it to complete their life cycles.

As fishers explain, the pink-shrimp is more abundant in places where there is 'grass' (the seagrass Ruppia maritima), and they are more available in windy days because in this condition shrimps are 
more likely to move. Argentine stiletto shrimp comes closer to the beach only when the northeast wind blows for at least a couple of days, and the southern kingfish comes from the south in the coldest waters.

Such examples demonstrate that the Peixe Lagoon fisherfolk hold the first level of TEK as classified by Berkes [7]. According to this author "traditional knowledge may be considered at several levels of analysis, consistent with the description of traditional ecological knowledge as a knowledge-practice-belief complex" [7, p. 13-14].

The first level relates to the local knowledge of the species and ecosystems, such as the fish behavior and habitat, and the timing of fishing seasons. This level of knowledge hold by Peixe Lagoon fishers has helped government officials and researchers in the last years to understanding specific environmental aspects of the Peixe Lagoon ecosystems [30,37].

The second level concerns the use of the TEK to devise an appropriate set of practices, tools and techniques for resource use [7]. Such knowledge creates ways of managing resources in a responsible way, adapting to local natural conditions for the maintenance of social-ecological resilience $[1,22]$. An example of this level of knowledge is the fishers' voluntary closure of pinkshrimp fisheries for allowing shrimps to grow to a size more valuable in the market. This conservation strategy was developed by local fishers independent of government management.

Other resource management strategy is the annual opening of the Lagoon mouth. As the Peixe Lagoon naturally closes its connection with the sea at the end of the summer, local people has annually done the opening of the Lagoon mouth at least since 1820 [40] allowing algae, nutrients and larvae of mollusks, crustaceans and fish to enter the Lagoon. This process results in a biological enrichment which has become part of the local ecological system, maintaining not only fisheries but also the food chain that sustains endemic and migratory birds.

Beyond management strategies, fishers need appropriate institutions - a set of social organizations - to manage effectively resources. Institutions are essential to establish co-ordination, cooperation, rules making and enforcement. Conservation and management of fishing resources can be improved by designing local institutions congruent with the species life cycles [24]. Accordingly, the third level of analysis is about institutions - the set of rules-in-use to coordinate resource management.

Peixe Lagoon fisherfolk established informal institutions based on the respect for traditional practices and agreed rules. For example, there are fishing spots 'owned' by fishers both in the lagoon and beach. Ownership is respected by all and sanctions are virtually unnecessary, despite the fact that there is no official document regulating this institution. Nevertheless, there have been physical sanctions (e.g. damage to nets) for fishers who disrespect the commonly agreed closure of the pink-shrimp fisheries. Locally devised institutions such as those just described can help to protect resources and to restrict over-exploitation as the enforcers are those who are in daily contact with the environment and rely on it for survival [7].

Lastly, the fourth 'worldview' level represents the system of belief (e.g. religion, ethics) that shapes human-nature relations and gives significance to social relationships. The main aspects that characterize and distinguish Peixe Lagoon fishers are related to long-term residence on their lands and to long-established ways of using and conserving natural resources. Their close relation to the environment is reflected in specific religious beliefs such as devotion to Santo Antonio and Nossa Senhora dos Navegantes or Iemanjá, which are spiritual figures believed to protect fishers during their activities in the sea. A specific way of speaking, naming places and natural phenomena, and producing handcrafts is another reflection of Peixe Lagoon fisher's origin and history, and their long-term residence in the same region [19].

Peixe Lagoon fishers' culture is an adaptation of the Azorean culture, which evolved for centuries after the arrival of the first immigrants to the Peixe Lagoon region, when they brought fishing techniques used in the Portuguese archipelago [47]. Their culture and way of living is closely related to the land, lagoon and ocean, which have been occupied and culturally appropriated for centuries. That has resulted in an apparently respectful relationship with the local environment which, combined with low capitalization and difficult access to markets, has resulted in minimal environmental impact.

The examples provided above demonstrate how the Peixe Lagoon fisherfolk have developed their levels of TEK in an intricate knowledge-practice-belief system closely related to the local environment. We argue that such TEK can be the basis of a resilient management system which fits protected area conservation purpose.

Table 3 summarizes the traditional ecological knowledge of the Peixe Lagoon fishers, matching it with TEK attributes considered relevant for environmental management according to Berkes.

\section{Nature conservation and traditional people: seeking reconciliation}

As showed in the Table 3, Peixe Lagoon fisherfolk constitutes traditional peoples. As such, SNUC requires that their ways of life, culture and knowledge be recognized and protected, which entails a revision of protected area status. Current legislation allows for changes on the category of conservation unit if it is demonstrated to be necessary.

National Park implementation in the Peixe Lagoon area will result, sooner or later, in the removal of fisherfolks from their residences and the ban on fisheries which serve as the basis for their livelihoods and culture. At the present, although they continue fishing and living in the Park, IBAMA imposes innumerable obstacles which are largely opposed by fisherfolk and their families. For example, fisherfolk are constrained in receiving visitors in their homes, and their houses continue to lack electricity and running water.

Conflicts are generated once IBAMA officials have, according to fisherfolk accounts, tried to restrict the most the activities of the local population within the protected area. Fishers complain that agents are hostile and do not respect their basic civil rights. IBAMA agents have been caught listening outside fishers' houses, entering their homes without permission, and setting fire to their fishing boats, vehicles and tents. Fisherfolk respond in kind, even to the point of physical violence against IBAMA agents. In a certain occasion the National Park superintendent had to leave the region as the conflict reached such intensity: fishers beat him up to the point of breaking his bones.

Because of such conflicts and constrains, fisherfolks are moving out the Park area without an appropriate management plan and a fair compensation, which violates their civil rights. Article fortytwo of Law 9985/00 and articles thirty-five and thirty-six of the Decree 4.340/2002 establish that traditional people, in the case of relocation, have to be relocated to places that could provide the same or better quality of life with guaranteed alternative ways of subsistence.

The question that should be critically addressed is: why do traditional Peixe Lagoon fisherfolk have to be removed from the protected area? We argue that those fishers who qualify as traditional people, which roughly correspond to those who currently hold temporary licenses, could, rather, be permanently integrated in protected area management with the adoption of measures to 
assure sustainable resource use. One of those measures would be the creation of an enforcement system in which traditional fishers would assist officials to protect resources from outsiders and from locals who do not depend on fishing for livelihoods (i.e. those who are not part of the traditional people).

Ecological sustainability should also be furthered through the collaborative creation and continual adaptation of fishing rules, including conservation measures, by fishers and Park scientists. The legalization of existing community-based resource management strategies would be part of this process, increasing trust between local population and state agents and decreasing the odds of rule breaking. Taking as an example successful community-based fisheries management accomplished by ribeirinho communities in the Brazilian Amazon, a collaborative monitoring, enforcement and decision-making system could be implemented, where rights to access resources would be tied to participation in the system [31]. Failure to comply with rules should have pre-determined sanctions, beginning with warnings at the community level, and the application of fines and even removal or rights for those who continue to break rules commonly devised and agreed.

Another problem with the assumption that fishers must be excluded from the protected area is that no study has been done to prove that the local fishing activities impact negatively Peixe Lagoon ecosystems. The only research project conducted prior to the period of the creation of the Park indicates that: (1) During the whole annual period of field observations carried out by the project, no negative impact was observed coming from fisherfolk, and (2) conservation of that area could be more effective if the population was not excluded, but rather partner of the monitoring of the Park by assisting governmental officials with rule enforcement in the area [38]. Almost 20 years after the creation of the Park, Loebmann [30] used ecological data to demonstrate that among the available technology in use, Peixe Lagoon fishers used the one with the lower impact over the most important targeted species, the pink-shrimp. In addition, it was found out that among the species most affected by 'by-catch', none had their populations significantly impacted.

Colchester [10] declares that because of the generalization of National Parks as a model of conservation, which was rapidly and widely accepted as a norm in South America [3,36], preservationists tend to think that they are legally obligated to relocate people from the conservation areas, even if there is no evidence that their presence threatens the local ecosystems or biodiversity.

In the case of the Peixe Lagoon National Park, little importance has been given to discussions about an eventual adequacy to a more appropriate category of conservation unit that would put forward a more efficient system of environmental protection without disrespecting the cultural identity and social security of the traditional people. Resource co-management is one alternative that could provide a mechanism towards the reconciliation of conservation policies with social justice in the Peixe Lagoon. Similar participatory initiatives have been happening in other lagoon complex in southern Brazil such as the Patos Lagoon $[23,26]$ and the Ibiraquera Lagoon [43].

\subsection{Institutions involved in decision-making in the Peixe Lagoon National Park: advancements towards a co-management arrangement}

Although the creation of the National Park was done in a topdown and centralized way, there are at present two main formal initiatives on the move towards a more participatory management of the Park. One is a discussion arena called 'Peixe Lagoon Fisheries Forum', which was created as a result of a series of conflicts, civil disobedience and a long battle between the local fishing communities and IBAMA. The other is the 'National Park Advisory Council', which is mandatory by SNUC.

The Peixe Lagoon Fisheries Forum was created in 1998 to serve as a discussion milieu providing conflict resolution mechanisms for the stakeholders that have interests related to fisheries management and exploitation in the Peixe Lagoon. The Fisheries Forum is composed basically of representatives of political authorities, IBAMA officials, EMATER ${ }^{1}$ agents and community fisher leaders. ${ }^{2}$

Political authorities such as the councilors of Tavares and Mostardas municipalities have been in the administration of the Fisheries Forum since its creation. They not only have the role of organizing meetings and invite stakeholders for discussion but also collect fishers' complaints and speak in favor of them in the presence of IBAMA officials. Although there is no official mediator, EMATER agents have taken this role, collaborating for the understanding between fishers and IBAMA. According to the Fisheries Forum administration, its main achievement was to make possible fishers to continue having access to resource through the concession of temporary licenses.

On the other hand, fishers recognize that Forum meetings occur basically to deal with immediate issues such as the date to open the fishing season or problems with enforcement staff. Meetings for discussing deeper issues such as long-term rights for fishers and their children to access resources do no take place since those are not available options for IBAMA. Another relevant limitation is that the Forum has what is called 'advisory status', which means that IBAMA does not necessarily have to adopt the decisions taken by forum members. Instead, the Forum is an arena for dialogue which can or cannot orient decisions taken by IBAMA, which is the only agency with the power to make the official decisions in regards to the protected area.

The National Park Advisory Council created in 2005 is composed of IBAMA, political authorities, representatives of public agencies, civil society organizations, land owners, universities, EMATER, NGOs, fisherfolk, among other stakeholders. Different from the Fisheries Forum, which is coordinated by fisherfolk's representatives, this Council is headed by IBAMA and its agenda is not restricted to fisheries issues. The decision-making process is very similar to the Fisheries Forum. During the period that the present research was being carried out, the Advisory Council was still in its early development, and it was not possible to evaluate its accomplishments and limitations. Nevertheless, it was evident that popular participation in the Advisory Council was higher than in the Fisheries Forum, and that other stakeholders were better organized and more connected than fishers. This was evident by the fact that their representatives were more articulated and IBAMA officials had a hard time responding to their arguments. In addition, fisher representatives found it difficult to bring attention to their issues during Advisory Council meetings, and complained that issues brought up by industry and farmer representatives occupied most of the discussion.

Since the creation of these multi-stakeholder bodies, fishers have been included in discussions concerning fisheries governance in the National Park, and have been able to participate in decisionmaking at a certain extent. Most of the decisions they contribute to are related to fisheries regulation (e.g. opening seasons, fishing gears prohibitions) and the management of the lagoon mouth. Through multi-stakeholder bodies, IBAMA officials have also had the opportunity to clarify to the local population their reasons to

\footnotetext{
${ }^{1}$ Company of Technical Assistance and Rural Extension.

2 Those leaders are simply community members and do not represent any syndicate or labor union.
} 
take certain decisions. This has been very important for increasing rapport with locals, since in the Brazilian context governmental agencies generally lack trust of citizens [46].

\subsection{The importance of promoting the involvement and participation of traditional people in the protected area management}

At first, one could argue that for the sake of obeying legislation, that is, respecting SNUC guidelines, traditional people should be allowed to maintain their livelihoods in their traditional lands. Beyond that, fishers could in fact collaborate in a great deal for sound PA management and environmental conservation for the following reasons:

a) Increasing support from local population: conservationists are becoming more conscious that effective environmental protection is only possible if the local communities support and can benefit from the implementation of conservation projects [36]. As the Peixe Lagoon National Park was created with little involvement of local peoples, a legitimate and effective implementation of the Park objectives has not been achieved. Part of it is due to the lack of appropriate policies and human resources. Borsato [8] argues that the population living in the Peixe Lagoon surroundings has a great potential to protect the National Park and only with their assistance an effective conservation of that area is possible.

b) Maintenance of a traditional management system: traditional people tend to defend their area from negative external interventions. An example of such situation is the Mamirauá Sustainable Development Reserve located in the Brazilian Amazon. In Mamirauá, a unique conservation management system was developed not following the traditional North American imported model of 'lost paradise' [15], but rather adjusting to the Brazilian context. Conservation is carried out through the participation of the local residents in managing the Reserve [29], successfully promoting conservation and social development at the same time [48]. The traditional fishing communities of the Peixe Lagoon highly depend on the lagoon ecosystems to guarantee their survival and the maintenance of their livelihoods. Because of that they have developed management strategies (e.g. territorial control, design of adaptive fishing seasons, lagoon mouth management) which contribute for the maintenance of ecosystems resilience.

c) Preservation of traditional ecological knowledge: the removal of traditional people from their territory may cause an irremediable loss of a unique and complex cumulative body of knowledge, practices and beliefs accumulated and transferred through generations. Peixe Lagoon fishers have accumulated empirical ecological knowledge which is a valuable tool for the management of local resources and environment. For instance, fisher's knowledge about the lagoon hydrological cycles and about pink-shrimp life cycle has resulted in management strategies that have been tested and developed for centuries consisting in a unique source of knowledge for the understanding of the local social-ecological system.

d) Maintenance of the singular culture of the Peixe Lagoon fisherfolk: if those people are removed from their territory and deprived from fishing in the lagoon, they will not only lose their means of survival but also their cultural identity. That is because their behavior, economic practices and institutions are closely linked to the Peixe Lagoon and fishing activities. Diegues [14] affirms that neither real estate speculation nor the establishment of protected areas should expel resource user communities from their lands, once the cultural diversity have been, each time more, considered a condition to the maintenance of biological diversity.

e) Assistance in management, monitoring and enforcement activities: the costs of protected area management are very high when local communities are not involved in it [36]. This issue is more important in developing countries where the lack of effective management historically has been associated with insufficient financial and human resources [32]. Fishing communities in the Peixe Lagoon have the potential for assisting IBAMA by providing knowledge, management strategies, enforcing informal rules and by pointing out environmental destructive practices in the National Park.

f) Avoiding unnecessary financial expenses and tensions related to relocation: relocation of traditional peoples may not only threaten protected areas but may also disorganize the habitats where populations are transferred to [10]. In addition, Arruda [4] argues that processes of traditional people relocation have contributed to enhance the crowded living situations in poor urban areas in Brazil, increasing problems related to urban unemployment and unequal wealth distribution. The great amount of resources that would be spent for the removal, replacement and creation of subsistence alternatives for the fisherfolk families could be used in the protection, recovery and management of ecosystems.

g) Minimization of social conflicts: the history of the Peixe Lagoon National Park is marked by civil disobedience, involving even physical violence. There are several accounts from both fishers and IBAMA agents of physical confrontation, resulting in burned houses, broken bones and use of fire guns. In 2003 more than a half of the population of Tavares city participated in a parade to demonstrate their dissatisfaction with IBAMA and to demand the rights of local peoples to live and work within the Park area. Sayer [42] affirms that the establishment of protected areas that disregard the aspirations, necessities and rights of the local populations, can create insoluble social problems that threaten the viability of the parks in the long run.

\section{Conclusion and recommendations}

As international drivers of protected areas evolve, they have clashed with issues of human rights and social justice. The Peixe Lagoon case is an illustrative one among many around the world, contributing to the discussion about incompatibility of no-take protected areas and livelihoods of traditional peoples where they co-exist.

This paper demonstrates that Peixe Lagoon fishers constitute traditional peoples according to the criteria commonly used in Brazil to define such societies. We argue that fisherfolk's livelihoods have not threatened either the ecosystems or the migratory birds protected by the National Park. As Diegues [17, p. 11] argued in his analysis on the myth of wilderness "not all inhabitants are "born conservationists', but among them there exist traditional people with a vast history of empirical knowledge about the natural world where they live". Based on that and on SNUC requirements for the recognition and protection of traditional people's ways of life, culture and knowledge we question whether National Park is the most appropriate category of conservation unit for the Peixe Lagoon.

Peixe Lagoon fishers hold rich traditional ecological knowledge attained and passed through generations for centuries. Such knowledge has been used to devise resource management strategies which, together with fisher willingness for cooperation with the environmental agency, can be useful for PA management. 
Traditional people long-term rights to access resources are defended together with measures that ensure sustainable use of resources and environmental protection.

Once rights are granted a system for shared decision-making, rule-creation, monitoring and enforcement between fishers and IBAMA agents would be an alternative model to the current topdown system. As in successful examples of co-management arrangements in the Brazilian Amazon, a system where fishers that do not contribute to monitoring resources and creating and enforcing rules should not have access to the benefits of the management system. Under the current PA legislation, the type of conservation unit should be switched from National Park to a sustainable use unit that allows human residency and resource co-management.

It is necessary to conserve biodiversity and ecosystems without compromising the social justice related to the lessfavored human populations which depend on the natural environment for food security. The implementation of an Extractive Reserve or a Sustainable Development Reserve is an alternative more appropriate to the Peixe Lagoon social-environmental system, allowing for a legitimate participatory management of the protected area.

As discussed by Becker [5, p. 299] "the appropriation of decisions concerning the use of territories and environment as value reserves, or in other words, without an immediate productive use, constitutes a means of control of natural capital for the future". There is an urgent need to share this control with those who are the most vulnerable, not allowing them to suffer from top-down interventions which also harm the objectives of environmental conservation. For the development of a collaborative management between the governmental agency and the traditional people, we suggest that furthering self-organization of the traditional fishers and training of protected area officials is indispensable.

The change in the approach for conservation during the last two decades was a result from the large scale failure of classic conservation approaches that separate human societies from nature. The Brazilian SNUC was created due to this recognized failure. Following this change, a paradigm shifts in the conservation model applied in the Peixe Lagoon is needed. One that recognizes the role of fishers traditional ecological knowledge for environmental conservation and that adapts to a new conservation approach (ethnoconservation), based on a non dichotomized relation between society and nature [15].

\section{Acknowledgements}

The authors thank Fikret Berkes and Brian Davy for reviewing this paper and the Brazilian National Council for Scientific and Technological Development (CNPq; Project number: 109984/ 2004-8 and process number: $800730 / 1990-9)$ for supporting this research. The support and cooperation from the fishing communities of the Peixe Lagoon and IBAMA officials were fundamental for the accomplishment of this work as well.

\section{References}

[1] Alcorn JB. Process as resource: the traditional agricultural ideology of Bora and Huastec resource management and its implications for research. Advances in Economics Botany 1989;7:63-77.

[2] Almudi T. Adequação do modelo de unidade de conservação: populações humanas, convivências e conflitos nos arredores da Lagoa do Peixe (RS). Honours Thesis, Brazil: Fundação Universidade Federal do Rio Grande; 2005.

[3] Amend S, Amend T. Human occupation in the National Parks of South America: a fundamental problem. Parks 1992;3:4-8.

[4] Arruda RSV. Populações Tradicionais e a Proteção dos Recursos Naturais em Unidades de Conservação. In: Diegues AC, editor. Etnoconservação: novos rumos para a proteção da natureza nos trópicos. São Paulo: Hucitec; 2000. p. 273-90.

[5] Becker B. Amazon frontiers at the beginning of the 21st century. In: Hogan D, organizer, editors. Human dimensions of global environmental change. Rio de Janeiro: Academia Brasileira de Ciências; 2001. p. 299-329.

[6] Berkes F, Folke C. Linking social and ecological systems. Management practices and social mechanisms for building resilience. Cambridge: Cambridge University Press; 1998. 459pp.

[7] Berkes F. Sacred ecology: traditional ecological knowledge and resource management. Philadelphia and London: Taylor and Francis; 1999. 313pp.

[8] Borsato LJ. Plano de Manejo do Parque Nacional da Lagoa do Peixe. Relatório Final. Rio Grande: Fundação Universidade Federal do Rio Grande/Instituto Brasileiro do Meio Ambiente e dos Recursos Naturais Renováveis, 1992.

[9] Brasil - Lei 9.985 de 18 de julho de 2000. Institui o Sistema Nacional de Unidades de Conservação (SNUC) e dá outras providências. Brasília, DF, 2000.

[10] Colchester M. Guyana's fragile Frontier: loggers, miners and forest peoples. United Kingdom: Latin America Bureau; 1997.

[11] Craven I. Community involvement in management of the Arfak Mountains Nature Reserve. Jacarta: World Wildlife Fund; 1990.

[12] Creswell J. Research design: qualitative and quantitative approaches. Beverly Hills: Sage; 1994. 228pp.

[13] Czaja R, Blair J. Designing surveys: a guide to decisions and procedures. Thousand Oaks: Pine Forge Press; 1996. 269pp.

[14] Diegues AC. Ecologia Humana e Planejamento Costeiro. São Paulo: Núcleo de Apoio à Pesquisa Sobre Populações Humanas e Àreas Úmidas Brasileiras Universidade de São Paulo; 2001. 225pp.

[15] Diegues AC. Etnoconservação: novos rumos para a proteção da natureza nos trópicos. São Paulo: Hucitec Ltda; 2000. 209pp.

[16] Diegues AC. O mito moderno da natureza intocada. São Paulo: Hucitec Ltda; 1996. 176pp.

[17] Diegues AC. The myth of wilderness and the fate of traditional communities in the Brazilian Amazon. International Association for the Study of Common Property Conference, Victoria Falls, Zimbabwe; 2002.

[18] Godelier M. Perspectives in Marxist anthropology. Paris: Maspero; 1973.

[19] Habiaga L. Aspectos Culturais. In: Tagliani PRA, editor. Arqueologia, história e socioeconomia da restinga da Lagoa dos Patos: uma contribuição para o conhecimento e manejo da reserva da biosfera. Rio Grande: Editora da FURG; 2000.

[20] Haggan N, Neiss B, Baird IG, editors. Fishers' knowledge in fisheries science and management. Coastal management sourcebooks No. 4. Paris: UNESCO; 2006. p. 437.

[21] Holling CS, Berkes F, Folke C. Science, sustainability and resource management. In: Berkes F, Folke C, editors. Linking social and ecological systems. Cambridge: Cambridge University Press; 1998. p. 342-61.

[22] Holling CS, Schindler DW, Walker BW, Roughgarden J. Biodiversity in the functioning of ecosystems: an ecological synthesis. In: Perrings C, Maler KG, Folke C, Holling CS, Jansson BO, editors. Biodiversity loss: economic and ecological issues. Cambridge: Cambridge University Press; 1995. p. 44-83.

[23] Kalikoski DC, Satterfield T. On crafting a fisheries co-management arrangement in the Estuary of Patos Lagoon (Brazil): opportunities and challenges faced through implementation. Marine Policy 2004;28:503-22.

[24] Kalikoski DC, Vasconcellos M, Lavkulich LM. Fitting institutions and ecosystems: the case of artisanal fisheries management in the Patos lagoon. Marine Policy 2002;26(03):179-96.

[25] Kalikoski DC, Vasconcellos M. Fishers knowledge role in the management of artisanal fisheries in the estuary of Patos Lagoon, southern Brazil. In: Neiss B, Haggan N, editors. Putting fishers' knowledge to work. Oxford: Blackwell; 2006.

[26] Kalikoski DC. The Forum of the Patos Lagoon: an analysis of co-management arrangement for conservation of coastal resources in Southern Brazil. Ph.D. Thesis, Canada: University of British Columbia; 2002.

[27] Knak RB, organizer. Plano de manejo do Parque Nacional da Lagoa do Peixe. Portaria 012/04. Brasília: IBAMA/FNMA/FURG/NEMA/UFPEL, 2004.

[28] Lee KN. Compass and gyroscope: integrating science and politics for the environment. Washington: Island Press; 1993. 243pp.

[29] Lima DM. Reserva Mamirauá. In: Capobianco JP, Araujo AV, editors. Unidades de conservação no Brasil: aspectos gerais, experiências inovadoras e a nova legislação (SNUC). Documentos do ISA, No. 1. São Paulo: Instituto Sócio Ambiental; 1996.

[30] Loebmann D. Caracterização da ictiofauna, crustáceos decápodos e avaliação do rejeito de pesca do camarão-rosa do Parque Nacional da Lagoa do Peixe, RS, Brasil. Master Thesis, Brazil: Fundação Universidade Federal do Rio Grande; 2004.

[31] McGrath DG, Cardoso A, Almeida OT, Pezutti J. Constructing a policy and institutional framework for an ecosystem-based approach to managing the Lower Amazon floodplain. Environment, Development and Sustainability 2008; 10:677-95.

[32] Medeiros R. A política de criação de áreas protegidas no Brasil: evolução, contradições e conflitos. In: Proceedings of the IV Congresso Brasileiro de Unidades de Conservação, Curitiba, Brazil, vol. 1; 2004. pp. 601-11.

[33] Ostrom E. Governing the commons: the evolution of institutions for collective action. New York: Cambridge University Press; 1990. 280pp.

[34] Pimbert M, Pretty J. Parks, people and professionals: putting participation in protected area management. In: Ghimire K, Pimbert M, editors. Social change and conservation. London: Earthcan; 1997. 
[35] Pimbert MP, Gujja B. Village voices challenging wetland management policies. Nature and Resources 1997;33:34-42.

[36] Pimbert MP, Pretty JN. Parks, people and professionals: putting 'participation' into protected area management. Discussion Paper No. 57. Geneva: UNRISD/ IIED/WWF-International, 1995 65pp.

[37] Resende S. Nobreeding strategies of migratory birds of Lagoa do Peixe, Rio Grande do Sul, Brazil. Masters Thesis, United States: Cornell University; 1988.

[38] Resende SL, Leeuwenberg F. Ecological studies of Lagoa do Peixe. Final Report World Wildlife Fund, 1987, 52pp.

[39] Robinson J, Franceis G, Legge R, Lerner S. Defining a sustainable society: values, principles and definitions. Alternatives 1990;17:36-46.

[40] Saint-Hillaire AD. Voyage a Rio Grande do Sul. Orleans: H. Herlison; 1887. 644pp.

[41] Sarkar S. Restoring wilderness or reclaiming florests. Terra Nova: Nature and Culture 1998;3(3):35-52.

[42] Sayer J. Rainforest buffer zones: guidelines for protected area managers. Gland: International Union for the Conservation of Nature; 1991. 94pp.

[43] Seixas CS, Berkes F. Dynamics of social-ecological changes in a lagoon fishery in southern Brazil. In: Berkes F, Colding J, Folke C, editors. Navigating socioecological systems. Cambridge: Cambridge University Press; 2003. p. 271-98.
[44] Seixas CS. Barriers to local-level, participatory ecosystem assessment and management in Brazil. In: Reid W, Berkes F, Wilbanks T, Capistrano D, editors. Bridging scales and knowledge systems: linking global science and local knowledge in assessments. Millennium Ecosystem Assessment. Island Press; 2006.

[45] Seixas CS. Social ecological dynamics in management systems: investigating a Coastal Lagoon Fishery in Southern Brazil. Ph.D. Thesis, Canada: University of Manitoba; 2002.

[46] Tagliani CRA, Hartmann C, Calliari L, Klein AP. Geologia e geomorfologia da Porção Sul do Parque Nacional da Lagoa do Peixe, RS, Brasil. In: Congresso Brasileiro de Geologia, 37, SBG/SP, São Paulo. Boletim de Resumos Expandidos 1992; 2:pp. 292-3.

[47] Tagliani PRA. Estratégia de planificação ambiental para o sistema ecológico da Restinga da Lagoa dos Patos-Planície Costeira do Rio Grande do Sul. Ph.D. Thesis, Brazil: Universidade de São Carlos; 1995.

[48] Viana JP, Damasceno JM, Castello L. Desarrollo del manejo pesquero comunitario en la reserva de Mamirauá, Amazonas, Brasil. In: Campos-Rozo C Ulloa A, editors. Fauna socializada. Tendencias en el manejo participativo de la fauna en América Latina. Bogotá: Fundación Natura, MacArthur Foundation, Instituto Colombiano de Antropología e Historia; 2003. p. 335-51. 